\title{
FORCE AND PEACE
}

\author{
By H. C. LodGe, \\ United States Senator.
}

In the general Commination service to which Carlyle devoted so much time and space he always found opportunity to hymn the praise of the strong, silent man who looked facts in the face. Very characteristically he dismissed with a sneer the most silent perhaps of all great men, one certainly who looked at the many hostile facts which he encountered in life with a steady gaze, undimmed by illusions, to a degree rarely equalled. I do not mean by this that Washington never spoke, never in speech or writing uttered his thoughts. Many volumes attest the supreme sufficiency of his dealings with all the crowding questions of war and peace which in such victorious manner he met and answered. But there was one subject upon which he held his peace, and that was himself. I once searched every printed line of his printed writings, as well as those of his contemporaries, and all that could be found in regard to the man himself were a few sentences of his own capable of an inference and elsewhere some stray anecdotes. We have his opinions, frank and free, on all the transactions of his life but nothing about himself. There silence reigns and hence he may be called in the truest sense the most silent of the great men of modern times. A very noble quality this, worthy of consideration in any age and especially in an age of much delivery of personal feelings and much self-advertising where publication is easy and passing notoriety extremely cheap. From the many necessary words, however, written and spoken by this most silent man upon all the far-reaching business of his life and about the world of men and things which he touched at so many points there emerge, very luminous and distinct, an unfailing power of looking facts, whether favorable or unfavorable, in the face, a fine freedom from illusions and complete refusal to admit self-deception or to attempt the deception of others. In these days when the readiness to accept words for deeds, language for action and a false or maudlin sentimentality for true sentiment, one of the noblest and purest of human motives; when, I repeat, 
the cheerful acceptance of these unrealities seems at least to be extremely prevalent, such veracity of mind and character as that possessed by Washington would appear more than usually worthy of contemplation and imitation.

I am well aware that in saying this I lay myself open to the familiar charge of having nothing to suggest but an effort to make ourselves resemble:

"Some of the simple great ones gone

Forever and ever by."

I can hear the well worn accusation coming from earnest and intelligent youth, that I am incapable of a new idea. Alas, it must be confessed that any man who has passed middle life would be dull indeed if he was not painfully aware of his incapacity in many directions. He knows that it is to youth he must look for the energy and faith which will keep the waters moving and save the world from stagnation. Whether it is hopeful, happy youth which cries out in the charming words of Miranda,

"How beautiful mankind is! O Brave, new world! That has such people in't:"

or Emerson's "fine, young, Oxford gentleman" who declares,

"There's nothing new and nothing true and no matter," or earnest youth, serious and sad, which, bending under the sense of responsibility, says with Hamlet,

"The time is out of joint; $\mathrm{O}$ cursed spite,

That ever I was born to set it right;"

all alike are interesting and attractive and awaken a melancholy envy in the breasts of those who have passed through the early shining years which to them are never to return. How keenly do we long to have all those fascinating attributes of the young and wise, to behold again all the fair visions of the morning of life. How we wish we could possess once more, whether as optimists, pessimists, or cynics, the finality, the completeness of judgment, the certainty of decision, the unfaltering condemnation of all who seem to differ with us in which we rejoiced in the days when the limits of life were hidden in the mists of the future. There are no compensations for such losses as these, but the merciless years bring at least their lessons, for they are the most effective if the most severe teachers to all who cannot avoid thought. He, whose 
mournful incapacity for the production of new ideas has come sharply home to him, has the added pang of knowing how eagerly he thirsts for those new ideas from others and how much his ability to recognize an old idea has been developed and increased. Setting aside the endless inventions and discoveries of science, he becomes aware of the extreme rarity of really new ideas in all that concerns society and government or the relation of men to each other. $\mathrm{He}$ takes up the book of intelligent and earnest youth in which the world is to be set right and after receiving the Rhadamanthine sentence upon himself and his coevals, a sentence from which there is no appeal, he sets out with the hope that springs eternal to find the new ideas for which he longs and which will solve the problems which have for so long pained and troubled him. He reads the book, clever, confident, often ingenious, not marked by a sense of humor, which is an older quality, but sure of everything and splendidly condemnatory of all differences of opinion. Then he lays it down with a sigh of disappointment. The ideas, however tricked out and newly dressed, are old friends with whom he has much more than a bowing acquaintance. They may be new to the writer, but they are old to the reader who has had the misfortune to live longer. So the reader, as so often before, tries to be philosophical and begins to reflect upon the alleviations for his disappointment. In relation to society and government it may be repeated that new ideas are rare; in regard to the latter, perhaps not more than two really large and new ideas have been developed in as many millenniums. Has not all progress, moreover, been attained chiefly by the energy of youth in striving to apply old ideas to changed environments and new conditions? There is comfort in the thought. The only suggestion to be made is that an ardent zeal to reform the world need not necessarily be accompanied by an entire recklessness in dealing with existing arrangements which have slowly been evolved and which represent the thoughts and hopes of mankind to which they have been adapted. It would seem that in making changes and what we believe to be advances by the application of old ideas to altered facts we should do well to remember that the prime factor in our many problems is human nature and that human nature, after all, is very permanent. I do not mean permanent in terms of the universe, which we have reason to think is never at rest, but permanent relatively within the very contracted limits 
of man's recorded history. This, by the way, is not a new idea. The best known of Roman poets wrote nearly two thousand years ago, "Naturam expellas furca, tamen usque recurret," and the thought, if ne'er so well expressed, was probably some thousands of years old when Horace wrote it down. Setting aside differences of place and race and time, which are largely superficial and perishable, there is nothing within our knowledge at once so uniform, so widely distributed and so unchanging, as human nature in its broad outlines and fundamental qualities.

A brilliant French critic has said that two great emotions have governed mankind and made his history -love and greed; the one as beautiful as the other is unlovely and potent. Whether these are the only ruling passions need not be discussed but they certainly are examples of two at least of the enduring elements in human nature. The young voices murmuring under the shadows of the great Pyramid in the days of Chefren;

\section{"the whispers}

Of plighted youth and maid,

In April's ivory moonlight

Beneath the chestnut shade,"

so beloved, we are told, of Venus, did not differ in essence from the words and vows interchanged by maidens and youths in appropriate circumstances under our own superior and more refined civilization. We may also be sure that selfishness has always been an attribute of human nature. I note this here because nations of whose affairs and relations I am about to speak are but aggregations of human beings and therefore selfishness is their attribute also, but with this important difference, that in masses of men it is almost never controlled or conquered by the nobler emotions as it is constantly and very splendidly in the individual man.

So it is that when we come to attempting changes in society or government, it is well to remember that the prime condition of our problem, human nature, is a permanent one and that the past, therefore, whether our guiding idea is most improbably new or is an old idea with a new adjustment, may possibly furnish some useful hints as to the method and outcome of such changes. I know by heart the reply to this suggestion: "Oh, that is all very well, but all these things happened a long time ago and everything is different now." As an objection, this, if I may venture to say so, 
has never appeared to me quite conclusive. The Ten Commandments happened a long time ago but that does not seem to justify us in not inculcating them today. It is nearly two thousand years since the beautiful and immortal teachings of the New Testament were given to mankind but no one, I imagine, would suggest that for that reason they should be laid aside. The Epistles of St. Paul, the dialogues of Socrates, the writings and discourses of Plato and Aristotle are all old as finite man computes time, but I should be sorry to dismiss them or refuse to consider them because of their age. The writings of these men dealt with what was most lasting in human nature, with right and wrong, with good and evil, with the highest morals, with things spiritual and things of this world. These thoughts were ancient at their birth and never have grown old. They are always old and always new. So it is with great men, the chosen exemplars of the race of man. Some of them at least have shown qualities which we may do well to study and imitate, which it might be wise to apply to our own problems as they applied them to theirs. Thus, after a long circuit, I come back to where I began. We, most fortunate, have one of these great men, who was also a good man, a very shining figure in the forefront of our nation's life. He dealt with life on a very large scale with high and rare success. One of his most salient qualities was the power of seeing facts just as they existed, without fear or favor, and therefore of meeting them with clear veracity of purpose and with all the strength of mind which had been granted him.

A great quality this, a great power, always much needed, as I have said, in our daily life here in the United States but more particularly demanded at this present moment when the world is facing one portentous and awful fact which has excluded almost everything else from the thoughts of men. For nearly a year that fact has been with us in the form of the most desolating and destructive war which has ever afflicted mankind. In this country, far removed from the scene of strife, with its daily existence flowing on untroubled, with its habits of life unbroken, untouched by the war until the wanton killing of unresisting men and helpless women and children on the Lusitania except in its trade, its commerce and its monetary interests, the great conflict is none the less ever present in our minds. Its dark shadow falls across the pathway which 
from day to day is trodden by each one of us. We wake in the morning with that vague sense of trouble which anxiety brings and which defines itself in sharp outline as the merciful oblivion of sleep passes away. Like a personal sorrow there comes between our eyes and the page we read, or the sheet of paper on which we write, a vision of fighting men and blood-stained trenches, of women and children homeless, outraged, mutilated, dead; of the houses of God and man shattered into hideous ruin. Our sympathies have been wakened as never before and have manifested themselves in a generous aid to the suffering across the ocean to a degree never shown by a neutral nation in all the recorded wars of history. To the unhappy and innocent people who in the twinkling of an eye have been deprived of a country and have found themselves cast forth, penniless wanderers upon the earth, we have held out our hands to lift them up with a generous kindness which will always be one of the best memories of the American people. If such has been the effect upon us, far distant, sheltered in our neutrality, how infinitely greater has been the effect upon the nations engaged in war and throughout those wide regions of Europe which for months have resounded with the clash of arms and where the air has been rent by the thunder of cannon and darkened by the dust and smoke of crumbled towns and desolated farms. In the presence of that vast struggle the interests, the habits of the life which seemed so permanent, have disappeared. The fantastic growths in art which absorbed the public attention and sought to make eccentricity pass for originality; the sexual novel, the effort to make us believe that clinical lectures and medical reports were drama, with much else of imaginary importance have withered in Europe before the fierce heat of the struggle of nations for life. The veils of what we call civilization have been torn away. Those conventions, which are merely its manifestations but which we are wont to mistake for fundamental principles, have been flung aside. An unrelenting, a grim reality stares us in the face. If we are to learn anything from it, if we are to do anything to prevent its return, we must first look at it with steady eyes and see just what it is. I am not concerned here with the rights or wrongs, with the guilt or the innocence of those engaged in the war, nor by reality do I mean the horrors of war. Every man and woman who can think knows what those horrors are. Death, destruction, physical anguish, sorrow, misery, 
have been before our eyes for months. The vocabulary has been worn out in describing them. There is no need of repeating more exhausted words when all words are vain. What we need to look at is the great dominant fact which stands out in the midst of all the horrors and all the fighting. I read a letter not long since from a young French officer who said that the one thing which filled his mind was not the daily danger and the constant suffering but the return of all about him, on both sides, to the condition of primitive man. In a few weeks they had crossed all the evolution of centuries with its slow upbuilding of civilization and returned to the state of mind which was of immemorial antiquity when the little space covered by our recorded history began. If we pause to think, although we ourselves are not engaged in the struggle, we shall realize that we have felt:

"That jar of our earth, that dull shock

When the plowshare of deeper passion

Tears down to our primitive rock."

And now what is it that is disclosed? We can put it all into a sentence. What we see is unchained physical force multiplied beyond computation by all the inventions and discoveries of an unresting science, as potent in destruction as it is in beneficence.

How is such a use of physical force, unlimited in its power, terrible in its consequences, to be avoided? How is peace to be established and maintained hereafter among the nations of the earth? One thing is certain, it cannot be done by words. Nothing will be accomplished by people who are sheltered under neutrality, gathering outside the edges of the fight and from comfortable safety summoning the combatants to throw down their arms and make peace because war is filled with horrors and women are the mothers of men. The nations and the men now fighting, as they believe, for their lives and freedom and national existence know all this better than any one else and would heed such babble, if they heard it, no more than the twittering of birds. In our Civil War when we were fighting for our national life, England and France and other outsiders were not slow in telling us that the Union could not be saved, that the useless carnage ought to cease, that peace must be made at once. Except as an irritating impertinence we regarded such advice as of no more consequence than the squeaking of mice behind the wainscot when fire has seized upon 
the house. Neither present peace, nor established peace in the future for which we hope, is helped by fervent conversation among ourselves about the beauties of peace and the horrors of war, interspersed with virtuous exhortations to others who are passing through the valley of the shadow, to give up all they are fighting for and accept the instructions of bystanders who are daring and sacrificing nothing and who have nothing directly at stake. Peace will not come in this way by vain shoutings nor by mere loudness in shrieking uncontested truths to a weary world. No men or women possessed of ordinary sense or human sympathies need arguments to convince them that peace among nations is a great good, to be sought for with all their strength, but the establishment and maintenance of peace cannot be accomplished by language proclaiming the virtues of peace and demonstrating the horrors of war. The many excellent people who may be described as habitual if not professional advocates of peace appear to be satisfied with uttering and listening to speeches about it. They seem to think great advances are made if we put our official names to a series of perfectly empty and foolish agreements which it is charitable to describe as harmless follies, for they weaken and discredit every real treaty which seeks to promote international good will and settle international differences. They are so vain and worthless that, when the hour of stress came, no one would think it worth while even to tear them up. Treaty agreements looking to the peaceful settlement of international disputes and which can be carried out are valuable to the extent to which they go, but treaty agreements which go beyond the point of practical enforcement, which are not meant to be enforced, and which have neither a sense of obligation nor force to sustain that obligation behind them, are simply injurious. If we are to secure our own peace and do our part toward the maintenance of world peace we must put rhetoric, whether in speech or on paper, aside. We must decline to be satisfied with illusions. We must refuse to deceive ourselves or others. We must pass by mere words and vague shows and come clear-eyed to the facts and the realities. The dominant fact today, I repeat, is the physical force now unchained in this great war. Some people seem to think that if you can abolish force and the instruments of force you can put an end to the possibilities 
of war. Let us for a moment go to the roots of existing things. Let us make the last analysis.

When I was a very young man I saw a large part of my native city swept away by fire in a single night. The calamity brought with it an enormous destruction of property, of the accumulated savings of years and much consequent suffering, both direct and indirect. What was the cause of this destruction and suffering? There was only one-fire. Not fire from the Heaven above or the earth beneath, but fire produced and used by man, set loose without control. The abolition of fire would undoubtedly have prevented a repetition of this disaster, but no one suggested it. The impossibility of attempting to stop the destruction of life and property through fire by abolishing fire itself was as apparent as its absurdity. Somewhere in the dim unwritten history of man upon earth a great genius, perhaps several great geniuses, discovered the production and control of fire. In the earliest traces of man there is, I think, as yet no proof of his existence without fire, and yet we know that at some period he must have discovered its production and control. Even when we come far down to the little fragment of time covered by man's recorded history we find that the thought of the production and control of fire as the greatest of discoveries still lingered in the human mind and found its expression in the symbolism of the beautiful Promethean myth. Fire, therefore, has probably been with man as his servant for a period which could only be expressed in the vast terms of geology. In large measure, society and civilization rest upon the use of fire. Without it, great spaces of the earth's surface would become not only useless to man but uninhabitable. Without it, the huge and intricate fabric of modern civilization in its present form would not exist. Therefore no argument is needed to convince men that the miseries and misfortunes caused by uncontrolled fire cannot be escaped by the abolition of fire itself. Relief must be sought not in abolition but in a better and wiser control which will render it difficult at least for man's best servant at any time to become his master. It is unchained force with the dread accompaniments of science which is today destroying life and limb, happiness, industry, property, and the joys and beauties of the art and devotion of the dead centuries. Is the terrible problem here presented to be solved by the abolition of the physical force possessed by nations? Go back again to the dark beginnings and study the 
comparatively few years, eight or ten thousand at the outside, of which we may be said to have a record.

In the dim light of that remote dawn we see men engaged in an unending conflict with the forces of nature, struggling with the wilderness, with wild beasts, with heat and cold and continually fighting with each other. Gradually they emerge in tribes with leaders, and then come states, communities, kingdoms, empires. But among all these confused events which make up history we find, I think, that the one fact which marks the development of every organized society, whether rude or complicated, of every political entity whether great or small, is the substitution of the will of the community and the protection of the community for the will of the individual and for the self-protection which each man naturally exercises. The one unfailing mark of what, for lack of a better word, we call civilization is this substitution of the force of the community, embodied in law and administered by what we describe as government, for the uncontrolled sporadic force of each individual member of the community. Wherever man is left to his own protection and his own defense there is nothing possible but personal fighting and general anarchy. The man possessed of the greatest physical force and the most effective weapons is the best protected. About him others gather and submit to his leadership and give him their support in return for his protection. Then we have the predutory band which found its highest expression in the feudal system. Gradually one band or lordship conquers or unites with itself other bands or lordships and they establish control over a certain territory; a state emerges, and the process is repeated on a larger scale by the conquest or union of other states. Physical is supplemented by intellectual force and we have at last the kingdom, the great republic or the mighty empire. But under it all lies the replacement of the scattered force of the individual by the consolidated force of the community and power, order, commerce, art and peace, rest in the last analysis upon the force of the community expressed in government of some sort, such government being merely its instrument and manifestation. You may carry your inquiry across the whole range of history and over the earliest human societies of which we have knowledge to the vigilance committees of the far West and you will find that law, order and peace, were brought about by men coming together and exercising the united force of the community, great or 
small, in order to put an end to the chaos and disorders of uncontrolled force exercised by each individual. When the civilization and the society reach a high point of organization, the underlying force upon which the entire social and political fabric rests is exerted and is often effective through what may be called merely a symbol. The longest period of general peace covering a large region of the earth of which we have knowledge in historic times was probably that of the Roman Empire, which endured for some three centuries. There was fighting on the widely extended frontiers at intervals diminishing in length as the end approached. After the decline began there were internal wars also at intervals with the imperial purple as the prize, but on the whole through the first three centuries of our era the general condition of the Roman Empire and throughout most of its extent was one of peace. That time is still referred to as the period of the Pax Romana.

In his romance of the "Last Days of Pompeii," Bulwer makes a dramatic point of the Roman sentry motionless at his post while the darkness and the flame and the burning flood were rushing down upon the doomed eity. That solitary sentry was the symbol of the force of the Roman Empire. Peace, order and law reigned throughout all western Europe, but it was the gleam upon the sword and corslet of the Roman legionary which made men realize that behind that law and peace and order was the irresistible force of the Empire of Rome. Even before that time the force which the sentry in Pompeii represented found like symbolic expression when the younger Scipio went upon a mission to the eastern kingdoms accompanied by only five servants. He went thus alone in safety and with respect attendant on his footsteps because behind him invisible but ever present was the fighting force of the dreaded Republic.

Let me take a more homely illustration. We have all seen in London and New York police officers stationed at points where the traffic is densest, regulating and guiding its movement by merely raising one hand. They would be perfectly incapable of stopping the vehicles carrying on that traffic, by their own physical force. It could pass over them and destroy them in a moment, and yet it is all governed by the gesture of one man. The reason is simple; the policeman is the symbol of the force of the community against which no individual force can prevail, and of this the great 
mass of individuals are thoroughly if unconsciously aware. Law is the written will of the community. The constable, the policeman, the soldier, is the symbol of the force which gives sanction to law and without which it would be worthless. Abolish the force which maintains order in every village, town and city in the civilized world and you would not have peace-you would have riot, anarchy and destruction; the criminal, the violent and the reckless would dominate until the men of order and the lovers of peace united and restored the force of the community which had been swept away. It is all obvious enough, it all rests on human nature, and if there was not somewhere an organized force which belonged to the whole community there would be neither peace nor order anywhere. No one has suggested, not even the most ardent advocates of peace, that the police of our cities should be abolished on the theory that an organization of armed men whose duty it is to maintain order, even if they are compelled often to wound and sometimes to kill for that purpose, are by their mere existence an incitement to crime and violence. If order, peace and civilization in a town, city or state, rest, as they do rest in the last analysis, upon force, upon what does the peace of a nation depend? It must depend, and it can only depend, upon the ability. of the nation to maintain and defend its own peace at home and abroad. Turn to the constitution of the United States. In the brief preamble one of the chief purposes of the constitution is set down as provision for the "common defense." In the grant of powers to Congress one of the first powers conferred is to provide for the "common defense of the United States." For this purpose they are given specific powers; to raise and support armies, to provide and maintain a navy, to provide for calling forth the militia, suppressing insurrections and repelling invasions. The states are forbidden to engage in war unless actually invaded, and the United States is bound to protect each of them against invasion and, on their request, to protect them also against domestic violence. In other words, the constitution provides for the maintenance of order at home and peace abroad through the physical force of the United States. The conception of the constitution is that domestic order as well as peace with other nations rests upon the force of the nation. Of the soundness of this proposition there can be no doubt, I think, in the mind of any reasonable man. This obvious principle embodied in the constitution and recognized by every organized govern- 
ment in the world is too often overlooked at the present moment in the clamor abainst armament. The people who urge the disarmament of one nation in an armed world confuse armament and preparation with the actual power upon which peace depends. They take the manifestation for the cause. Armament is merely the instrument by which the force of the community is manifested and made effective, just as the policeman is the manifestation of the force of the municipal community upon which local order rests. The fact that armies and navies are used in war does not make them the cause of war, any more than maintaining a fire in a grate to prevent the dwellers in the house from suffering from cold warrants the abolition of fire because where fire gets beyond control it is a destructive agent. Alexander the Great was bent on conquest and he created the best army in the world at that time, not to preserve the peace of Macedonia but for the purpose of conquering other nations, to which purpose he applied his instrument. The wars which followed were not due to the Macedonian phalanx but to Alexander. The good or the evil of national armament depends not on its existence or its size but upon the purpose for which it is created and maintained. Great military and naval forces created for purposes of conquest are used in the war which the desire of conquest causes. They do not in themselves cause war. Armies and navies organized to maintain peace serve the ends of peace because there is no such incentive to war as a rich, undefended and helpless country, which by its condition invites aggression. The grave objections to overwhelming and exhausting armaments are economic. A general reduction of armaments is not only desirable but is something to be sought for with the utmost earnestness. But for one nation to disarm and leave itself defenseless in an armed world is a direct incentive and invitation to war. The danger to the peace of the world then lies not in armament, which is a manifestation, but in the purposes for which the armament was created. A knife is frequently dangerous to human life, but there would be no sense in abolishing knives because the danger depends solely on the purpose or passion of the individual in whose hand the knife is and not upon the fact that the knife exists. The peace of a nation depends in the last resort, like domestic order, upon the force of the community and upon the ability of the community to maintain peace, assuming that the nation lives up to its obligations, seeks no con- 
quest, and wishes only to be able to repel aggression and invasion. If a nation fulfills strictly all its international obligations and seeks no conquest and has no desire to wrong any other nation, great or small, the danger of war can come only through the aggression of others, and that aggression will not be made if it is known that the peace-loving nation is able and ready to repel it. The first step then toward the maintenance of peace is for each nation to maintain its peace with the rest of the world by its own honorable and right conduct and by such organization and preparation as will enable it to defend its peace.

This should be our policy. We should show the world that democracy, government by the people, makes for peace, in contrast to the government of a military autocracy which makes for war. We should demonstrate this by our own conduct, by justice in our dealings with other nations, by readiness to make any sacrifices for the right and stern refusal to do wrong; by deeds, not words, and finally by making the whole world understand that while we seek no conquests we are able to repel any aggression or invasion from without for the very reason that we love peace and mean to maintain it. We should never forget that if democracy is not both able and ready to defend itself it will go down in subjection before military autocracy because the latter is then the more efficient. We must bear constantly in mind that from the conflict which now convulses the world there may possibly come events which would force us to fight with all our strength to preserve our freedom, our democracy and our national life. But this concerns ourselves and will only have the slow moving influence of example. What can be done now? What can we do in the larger sense toward securing and maintaining the peace of the world? This is a much more difficult question, but turn it back and forth as we may there is no escape from the proposition that the peace of the world can only be maintained, as the peace and order of a single community are maintained, as the peace of a single nation is maintained, by the force which united nations are willing to put behind the peace and order of the world. Nations must unite as men unite in order to preserve peace and order. The great nations must be so united as to be able to say to any single country, you must not go to war, and they can only say that effectively when the country desiring war knows that the force which the united nations place behind peace is irresistible. 
We have done something in advancing the settlement by arbitration of many minor questions which in former times led to wars and reprisals, although the points of difference were essentially insignificant, but as human nature is at present constituted and the world is at present managed there are certain questions which no nation would submit voluntarily to the arbitration of any tribunal, and the attempt to bring such questions within the jurisdiction of an arbitral tribunal not only fails in its purpose but discredits arbitration and the treaties by which the impossible is attempted. In differences between individuals the decision of the court is final, because in the last resort the entire force of the community is behind the court decision. In differences between nations which go beyond the limited range of arbitrable questions peace can only be maintained by putting behind it the force of united nations determined to uphold it and to prevent war. No one is more conscious than I of the enormous difficulties which beset such a solution or such a scheme, but I am certain that it is in this direction alone that we can find hope for the maintenance of the world's peace and the avoidance of needless wars. Even if we could establish such a union of nations there might be some wars which could not be avoided, but there are certainly many which might be prevented.

It may be easily said that this idea, which is not a new one, is impracticable, but it is better than the idea that war can be stopped by language, by speechmaking, by vain agreements which no one would carry out when the stress came, by denunciations of war and laudations of peace, in which all men agree, for these methods are not only impracticable but impossible and barren of all hope of real result. It may seem Utopian at this moment to suggest a union of civilized nations in order to put a controlling force behind the maintenance of peace and international order, but it is through the aspiration for perfection, through the search for Utopias, that the real advances have been made. At all events it is along this path that we must travel if we are to attain in any measure to the end we all desire of peace upon earth. It is at least a great, a humane, purpose to which, in these days of death and suffering, of misery and sorrow among so large a portion of mankind, we might well dedicate ourselves. We must begin the work with the clear understanding that our efforts will fail if they are tainted with the thought of personal or political profit or with any idea of self-interest or self- 
glorification. We may not now succeed, but I believe that in the slow process of the years others who come after us will reach the goal. The effort and the sacrifice which we make will not be in vain when the end in sight is noble, when we are striving to help mankind and lift the heaviest of burdens from suffering humanity. 